\title{
Modeling grassland net primary productivity and water-use efficiency along an elevational gradient of the Northern Tianshan Mountains
}

\author{
QiFei HAN ${ }^{1,2}$, GePing LUO ${ }^{1 *}$, ChaoFan $\mathrm{LI}^{1,2}$, Hui YE ${ }^{1,2}$, YaoLiang CHEN ${ }^{1,2}$ \\ ${ }^{1}$ State Key Laboratory of Desert and Oasis Ecology, Xinjiang Institute of Ecology and Geography, Chinese Academy of Sciences, \\ Urumqi 830011, China; \\ ${ }^{2}$ University of Chinese Academy of Sciences, Beijing 100049, China
}

\begin{abstract}
Mountainous ecosystems are considered highly sensitive and vulnerable to natural disasters and climatic changes. Therefore, quantifying the effects of elevation on grassland productivity to understand ecosystem-climate interactions is vital for mountainous ecosystems. Water-use efficiency (WUE) provides a useful index for understanding the metabolism of terrestrial ecosystems as well as for evaluating the degradation of grasslands. This paper explored net primary productivity (NPP) and WUE in grasslands along an elevational gradient ranging from 400 to $3,400 \mathrm{~m}$ asl in the northern Tianshan Mountains-southern Junggar Basin (TMJB), Xinjiang of China, using the Biome-BGC model. The results showed that: 1) the NPP increased by $0.05 \mathrm{~g} \mathrm{C} /\left(\mathrm{m}^{2} \cdot \mathrm{a}\right)$ with every increase of 1-m elevation, reached the maximum at the mid-high elevation $(1,600 \mathrm{~m}$ asl $)$, and then decreased by $0.06 \mathrm{~g}$ $\mathrm{C} /\left(\mathrm{m}^{2} \cdot \mathrm{a}\right)$ per $1-\mathrm{m}$ increase in elevation; 2$)$ the grassland NPP was positively correlated with temperature in alpine meadow (AM, 2,700-3,500 m asl), mid-mountain forest meadow (MMFM, 1,650-2,700 m asl) and low-mountain dry grassland (LMDG, 650-1,650 m asl), while positive correlations were found between NPP and annual precipitation in plain desert grassland (PDG, lower than $650 \mathrm{~m}$ asl); 3) an increase (from 0.08 to $1.09 \mathrm{~g} \mathrm{C} /\left(\mathrm{m}^{2} \cdot \mathrm{a}\right)$ ) in mean NPP for the grassland in TMJB under a real climate change scenario was observed from 1959 to 2009; and 4) remarkable differences in WUE were found among different elevations. In general, WUE increased with decreasing elevation, because water availability is lower at lower elevations; however, at elevations lower than $540 \mathrm{~m}$ asl, we did observe a decreasing trend of WUE with decreasing elevation, which may be due to the sharp changes in canopy cover over this gradient. Our research suggests that the NPP simulated by Biome-BGC is consistent with field data, and the modeling provides an opportunity to further evaluate interactions between environmental factors and ecosystem productivity.
\end{abstract}

Keywords: elevational gradient; net primary production; water-use efficiency; climate

Citation: QiFei HAN, GePing LUO, ChaoFan LI, Hui YE, YaoLiang CHEN. 2013. Modeling grassland net primary productivity and water-use efficiency along an elevational gradient of the Northern Tianshan Mountains. Journal of Arid Land, 5(3): 354-365.

Mountain ecosystems are a vital component of the global biogeosphere and are widely recognized as being highly diverse (Peng et al., 2008). At the same time, as illustrated by Messerli and Ives (1997), mountain ecosystems are considered highly sensitive and vulnerable to climatic changes and natural disas- ters (Thompson, 2000; Diaz et al., 2003). The investigations of mountain ecosystems may provide critical insights into understanding climate variability and its impacts. Among all the indicators of ecosystem function, terrestrial net primary productivity (NPP) is considered a major one because it represents the greatest

*Corresponding author: GePing LUO (E-mail: luogp@ms.xjb.ac.cn) Received 2013-02-05; revised 2013-04-20; accepted 2013-05-02

(C) Xinjiang Institute of Ecology and Geography, Chinese Academy of Sciences, Science Press and Springer-Verlag Berlin Heidelberg 2013 
annual carbon flux from the atmosphere to the biosphere (Hall et al., 1995; Churkina and Running, 1998).

Elevation has profound effects on ecosystem function, and thus, on primary production (Luo et al., 2004) and land degradation processes (Drewnik, 2006). The quantification of NPP along an elevational gradient, then, is a significant research focus. Moreover, elevation is a complex gradient that represents several covarying environmental variables, including temperature and precipitation (Austin et al., 1996; Zhang et al., 2012). These variables solely and interactively affect NPP. Among factors controlling ecosystem functioning in mountainous areas, precipitation is vital, especially in arid ecosystems (Bai et al., 2008; Ning et al., 2012). Indeed, because global climate change is likely to produce more frequent extreme precipitation and drought events (Easterling et al., 2000; Repetto and Easton, 2010; Cheng et al., 2012), precipitation may have greater impacts than elevated $\mathrm{CO}_{2}$ and temperature alone or combined (Melillo et al., 1993; Weltzin et al., 2003). Therefore, clarifying how precipitation affects productivity in grasslands is critical for predicting the impact of global climate change on the functioning of these ecosystems (Knapp et al., 2002; Weltzin et al., 2003; Hu et al., 2010).

Water-use efficiency (WUE) defines how efficiently individual plants use water to produce biomass (LeHouerou, 1984) and it provides a useful index for understanding the metabolism of terrestrial ecosystems as well as for evaluating the degradation of grasslands (Justice et al., 1991; Prince et al., 1998). Various studies have shown that WUE often increases as water availability decreases in dryland ecosystems (Ehleringer and Cooper, 1988; Toft et al., 1989; Shen et al., 2011). However, as shown by DeLucia and Schlesinger (1991), the drought tolerance of desert plants has not been correlated with high WUE. Therefore, it is unclear how vegetations in different ecosystems that span a water availability gradient respond to changes in water availability. Thus, clearly examining the variations in WUE across the elevational gradient is useful for predicting the effects of climate change on vegetation productivity.
One of the primary methods for estimating ecosystem function is to utilize process models, which are built based on physiological and ecological processes. The Biome-BGC model is such a process model and is driven by daily climate data (maximum and minimum air temperature, precipitation) and the definition of several key climate, vegetation, soil and site conditions to estimate the dynamics of energy, water, carbon and nitrogen in a defined type of terrestrial ecosystem (Running and Coughlan, 1988; Running and Hunt, 1993). Biome-BGC is designed to represent seven natural biomes, including evergreen needleleaf, evergreen broadleaf, deciduous needleleaf, deciduous broadleaf forests, shrubs, $\mathrm{C}_{3}$ and $\mathrm{C}_{4}$ grasses. (Cienciala and Tatarinov, 2006; Schmid et al., 2006; Tatarinov and Cienciala, 2006; Chiesi et al., 2007). However, The early applications of Biome-BGC principally focused on forests. It is rare to find its application in grassland ecosystems.

The Central Eurasia continent, the largest arid land in the world, is characterized by landscapes of large mountainous basins and the climate was featured as distinct vertical gradients. Northern Tianshan Mountains-southern Junggar Basin (TMJB), located in the center of the Central Eurasia continent, has representative grasslands, and as a result, is very meaningful for global carbon cycling research to estimate the ecosystem function of grasslands.

Therefore, this study was designed to investigate the variation of NPP and WUE and their underlying mechanisms based on the Biome-BGC model in an arid mountain ecosystem in TMJB. Specifically, we performed the following tasks: 1) validate the BIOME-BGC model for a grassland ecosystem; 2) quantify the changes in NPP and the impacts of a changing climate on NPP along an altitudinal gradient in the past 50 years; and 3) identify how WUE varies along the altitudinal gradient.

\section{Study area}

The study area extends from the northern Tianshan Mountains to the southern Junggar Basin. Four biogeographic types of grasslands exist along the elevational gradient (Table 1): alpine meadow (AM, 
2,700-3,500 $\mathrm{m}$ asl), mid-mountain forest meadow (MMFM, 1,650-2,700 m asl), low-mountain dry grassland (LMDG, 650-1,650 m asl), and plain desert grassland (PDG, lower than $650 \mathrm{~m}$ asl). The mean annual precipitation and annual mean temperature in the MMFM recorded at the Tianchi meteorological station were respectively $592 \mathrm{~mm}$ and $2.2^{\circ} \mathrm{C}$ during the period 1959-2009. Seventy percent of the annual precipitation falls between May and September. The mean annual potential evaporation is $1,368 \mathrm{~mm}$. The $\mathrm{AM}$ is covered by alpine or sub-alpine meadow.
Above the AM belt $(3,500-4,000 \mathrm{~m})$, the ground surface is bare or covered by modern glaciers and permanent snow. In the MMFM, the sunny hillside is mainly covered by grasses with a coverage of greater than $70 \%$. LMDG, located at the transition between the mountain and the basin, is characterized by dry grassland or desert shrub land with a coverage of $30 \%-80 \%$. According to the precipitation/evaporation ratio, plants growing in the PDG and LMDG are subject to water stress, but not those growing in the MMFM and AM (Luo et al., 2012).

Table 1 Details of the grasslands along the elevational gradient in the northern Tianshan Mountains and southern Junggar Basin (TMJB) between 1959 and 2009

\begin{tabular}{llcccc}
\hline Grassland & Altitude $(\mathrm{m})$ & Temperature $\left({ }^{\circ} \mathrm{C}\right)$ & Precipitation $(\mathrm{mm})$ & Potential evaporation $(\mathrm{mm})$ & Precipitation /evaporation \\
\hline PDG & $<650$ & 10.3 & 228 & 1,753 & 0.13 \\
LMDG & $650-1,650$ & 8.3 & 315 & 926 & 0.34 \\
MMFM & $1,650-2,700$ & 2.2 & 592 & 661 & 0.90 \\
AM & $2,700-3,500$ & -0.2 & 501 & 748 & 0.67 \\
\hline
\end{tabular}

Note: PDG, plain desert grassland; LMDG, low-mountain dry grassland; MMFM, mid-mountain forest meadow; AM, alpine meadow.

\section{Materials and methods}

\subsection{The Biome-BGC model}

Biome-BGC is a process-based model that simulates the storage and fluxes of water, carbon and nitrogen between different compartments in the ecosystem and the atmosphere (Kimball et al., 1997; Lagergren et al., 2006). This model is an extension and generalization of the forest-BGC model for the description of different vegetation types, including $\mathrm{C}_{3}$ and $\mathrm{C}_{4}$ grasslands (Running and Hunt, 1993). The model operates on a daily time step and requires meteorological input data such as daily minimum and maximum temperature, incident solar radiation, vapor pressure deficit and precipitation. Net primary production (NPP) was calculated using gross primary production (GPP) according to the Farquhar photosynthesis routine (Farquhar et al., 1980) minus the autotrophic respiration. The autotrophic respiration includes the maintenance respiration and growth respiration. Maintenance respiration is calculated as a function of the tissue nitrogen concentration (Ryan, 1991). Growth respiration is a function of the amount of carbon allocated to different plant compartments (leaf, root, and stem)
(Petritsch et al., 2007). The model has three compartments: vegetation, litter, and soil. Each compartment is subdivided into four pools on the basis of differences in their function: leaf, stem, coarse roots, and fine roots.

In the hydrology scheme of the model, evapotranspiration (ET) is estimated as the sum of transpiration, evaporation from the soil and canopy, and sublimation (Kimball et al., 1997), and is calculated using a Penman-Monteith model (Running and Coughlan, 1988). Soil conductance is assessed from the number of days after rainfall. Canopy evaporation is estimated from the amount of water intercepted by the canopy. Transpiration is regulated by the canopy conductance under the daily meteorological conditions of the minimum air temperature, vapor pressure deficient (VPD), solar radiation, and soil water availability (Ito and Inatomi, 2012). Further details of the Biome-BGC model have been described in previous publications (Running and Hunt, 1993; Kimball et al., 1997; Ueyama et al., 2010; Hidy et al., 2012).

\subsection{Field datasets}

Three types of information are required by the $\mathrm{Bi}$ ome-BGC model: site parameters, meteorological data, 
and vegetation data, which were systematically observed at several sites to allow a reliable parameterization of this model. Meteorological data such as daily precipitation, mean, maximum and minimum air temperature, solar radiation, and day length were obtained from the Tianchi meteorological station for 19592009 (1,923 $\mathrm{m}$ asl), the Fukang meteorological station for 1970-2009 (547 m asl), the Qitai meteorological station for 1960-2008 (560 m asl), and the Bayinbuluke automatic meteorological station for 2000-2009 (2,577 $\mathrm{m}$ asl). Other meteorological variables (for example, radiation and daytime vapor pressure) or variables for other places required by the Biome-BGC were derived using the microclimate simulator MTCLIM, which provides an estimation of the missing meteorological variables based on measurements of temperature, precipitation, geographical and topographical information such as latitude, longitude, elevation, slope, and aspect (Thornton and Running, 1999; Thornton et al., 2000).

Field experiments were carried out in the Tianshan Mountains and southern Junggur Basin (Fig. 1). For vegetation observations, sites which are regarded to be representative of different types of grasslands are chosen: Qitai mountainous area in the eastern section of the northern Tianshan Mountains, Qitai desert area in the south-eastern Junggur Basin, and Bayinbuluke meadow area at about $2,570 \mathrm{~m}$ asl in the middle section of the southern Tianshan Mountains. The values of aboveground biomass were averaged from at least 5 measurements on a quadrat of $1 \mathrm{~m} \times 1 \mathrm{~m}$. All living plants in each quadrat were clipped at ground level. Aboveground biomass was dried at $65^{\circ} \mathrm{C}$ for $48 \mathrm{~h}$ and weighed. Because the standing crops of these steppe and desert communities reached their peak at the middle to end of August, the estimated community biomass approximated aboveground net primary production (ANPP) of these ecosystems. Detailed information about the surveys was given in Luo et al. (2012) (Table 2). For validation of ET, a Bowen ratio system (Jauntering International Inc., Taipei, Taiwan, China) was installed at the elevation of $1,500 \mathrm{~m}$ asl in Urumqi county (fig. 1), in 2012. The latent heat flux (Le) was measured at a time step of an hour. The flowing equation was used to calculate ET:

$$
\mathrm{ET}=\mathrm{Le} / \lambda \text {. }
$$

Where, $\lambda$ equals to $2.4 \times 10^{6} \mathrm{w} /\left(\mathrm{m}^{2} \cdot \mathrm{mm}\right)$.

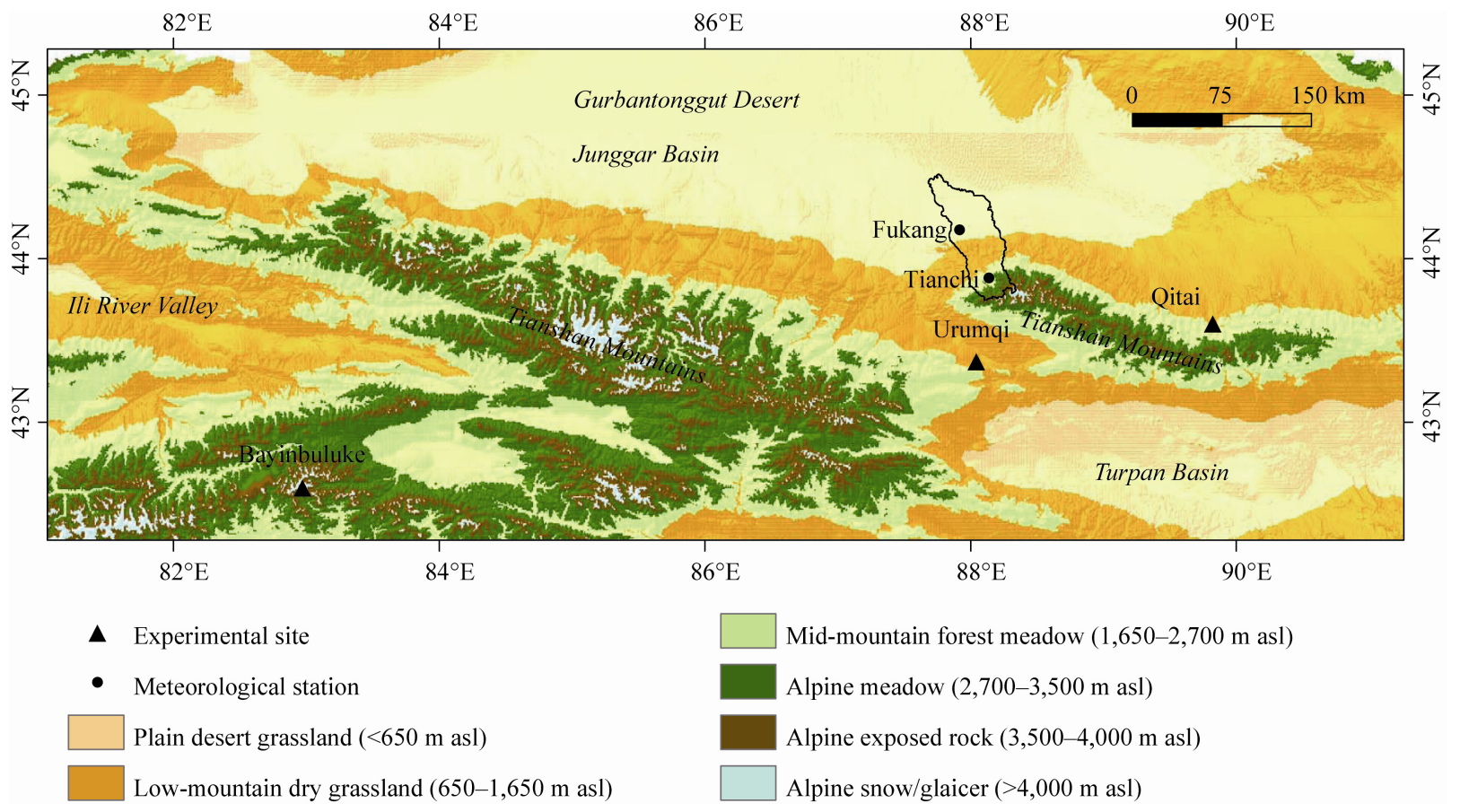

Fig. 1 Sketch map of the study area, the northern Tianshan Mountains and southern Junggur Basin 
Table 2 Detailed information of the field survey sites in TMJB

\begin{tabular}{|c|c|c|c|c|c|c|c|}
\hline Location & Grassland & Altitude (m) & Latitude & Longitude & Temperature $\left({ }^{\circ} \mathrm{C}\right)$ & Precipitation $(\mathrm{mm})$ & Detailed field measurement \\
\hline \multirow{6}{*}{ Qitai } & \multirow[t]{2}{*}{ PDG } & 622 & $44^{\circ} 28.22^{\prime} \mathrm{N}$ & $89^{\circ} 54.49^{\prime} \mathrm{E}$ & \multirow{2}{*}{9.15} & \multirow{2}{*}{187} & \multirow{2}{*}{$\begin{array}{l}\text { Yearly aboveground biomass measured inside } \\
\text { and outside the enclosure during } 2008\end{array}$} \\
\hline & & 712 & $44^{\circ} 17.52^{\prime} \mathrm{N}$ & $90^{\circ} 04.25^{\prime} \mathrm{E}$ & & & \\
\hline & LMDG & 1,356 & $43^{\circ} 46.05^{\prime} \mathrm{N}$ & $89^{\circ} 24.39^{\prime} \mathrm{E}$ & \multirow[t]{2}{*}{9.24} & \multirow[t]{2}{*}{281} & \multirow{2}{*}{$\begin{array}{l}\text { Yearly aboveground biomass measured inside } \\
\text { and outside the enclosure between } 2007 \text { and } \\
2008 \text { and latent heart flux in } 2012\end{array}$} \\
\hline & & 2,144 & $43^{\circ} 33.34^{\prime} \mathrm{N}$ & $83^{\circ} 33.34^{\prime} \mathrm{E}$ & & & \\
\hline & \multirow[t]{2}{*}{ MMFM } & 2,027 & $43^{\circ} 34.59^{\prime} \mathrm{N}$ & $89^{\circ} 45.23^{\prime} \mathrm{E}$ & \multirow[t]{2}{*}{2.15} & \multirow[t]{2}{*}{386} & \multirow{2}{*}{$\begin{array}{l}\text { Yearly aboveground biomass measured inside } \\
\text { and outside the enclosure between } 2007 \text { and } \\
2008\end{array}$} \\
\hline & & 2,120 & $43^{\circ} 33.30^{\prime} \mathrm{N}$ & $89^{\circ} 45.44^{\prime} \mathrm{E}$ & & & \\
\hline BYBLK & MMFM & 2,577 & $42^{\circ} 52.48^{\prime} \mathrm{N}$ & $83^{\circ} 42.10^{\prime} \mathrm{E}$ & 1.86 & 260 & $\begin{array}{l}\text { Yearly aboveground biomass measured dur- } \\
\text { ing 2004-2009 in the enclosure }\end{array}$ \\
\hline
\end{tabular}

Note: PDG, plain desert grassland; LMDG, low-mountain dry grassland; MMFM, mid-mountain forest meadow; BYBLK, Bayinbuluke.

\subsection{Evaluation of model prediction and simulation setup}

To ascertain the performance of Biome-BGC, model validation was conducted using the simulated and observed NPP and ET at the elevational gradient. Model goodness-of-fit was evaluated by using the root mean square error (RMSE) to characterize the mismatch of the calculated values against the observed values.

Thirty-three parameters are essentially required for the spin up of the Biome-BGC model (Luo et al., 2012). The NPP and ET for grasslands were simulated using Biome-BGC model by an altitudinal interval of approximately $200 \mathrm{~m}$. The points were approximately spaced at the same longitude and latitude. To ascertain the separate effects of temperature and precipitation on NPP along the elevational gradient, three sets of simulations were designed: (1) PreTem, driven by the present precipitation and temperature data; (2) TemVar, which was simulated using 51-year average precipitation and real temperature data; and (3) PreVar, which simulates NPP with 51-year average temperature and real precipitation data. PreTem was used to estimate the NPP during 1959-2009. The effects of temperature alone on the carbon cycle were obtained from the results simulated by TemVar. Precipitation effects were estimated from the results of PreVar.

WUE can be defined in many ways. On an ecosystem scale, three major definitions were generally used: (1) gross primary production (GPP)-based WUE: GPP/ET; (2) net primary productivity (NPP)-based WUE: NPP/ ET; and (3) net ecosystem carbon production (NEP)-based WUE: NEP/ET. Annual rainfall was also used to replace ET to calculate rainfall-use efficiency (RUE) (Huxman et al., 2004; Bai et al., 2008). In this study, the ecosystem-level WUE was calculated as the annual NPP divided by the annual ET (WUE $=\mathrm{NPP} / \mathrm{ET}$ ), where NPP and ET were modeled from Biome-BGC.

\section{Results}

\subsection{Comparisons between simulated and observed aboveground net primary productivity}

The differences between observed and simulated aboveground net primary productivity (ANPP) along the elevation gradient were shown in Fig. 2. The comparison of measured and modeled NPP were constricted to ANPP, because of the limitation of colleting underground biomass. It is obvious that the fit of the simulated ANPP to the observed data is good for the whole set of analyzed elevations. The average measured annual ANPP in the Qitai area was $38.46 \mathrm{~g}$ $\mathrm{C} /\left(\mathrm{m}^{2} \cdot \mathrm{a}\right)$, and the model predicted $35.78 \mathrm{~g} \mathrm{C} /\left(\mathrm{m}^{2} \cdot \mathrm{a}\right)$; the average measured annual ANPP in the BYBLK area was $18.63 \mathrm{~g} \mathrm{C} /\left(\mathrm{m}^{2} \cdot \mathrm{a}\right)$, and the model predicted $24.94 \mathrm{~g} \mathrm{C} /\left(\mathrm{m}^{2} \cdot \mathrm{a}\right)$. The relative error $(\mathrm{RE})$ was $7.4 \%$ and $21 \%$, and RMSE was $6.18 \mathrm{~g} \mathrm{C} /\left(\mathrm{m}^{2} \cdot \mathrm{a}\right)\left(R^{2}=0.79\right)$ and $0.42 \mathrm{~g} \mathrm{C} /\left(\mathrm{m}^{2} \cdot \mathrm{a}\right)\left(R^{2}=0.42\right)$, respectively. Figure 3 illustrates that the actual ET between July 2012 and November 2012 has an accuracy of RMSE (0.59 $\left.\mathrm{kg} /\left(\mathrm{m}^{2} \cdot \mathrm{d}\right), R^{2}=0.63\right)$. The ET was generally higher during the middle growing season (July-August) and lower during the late growing season. 

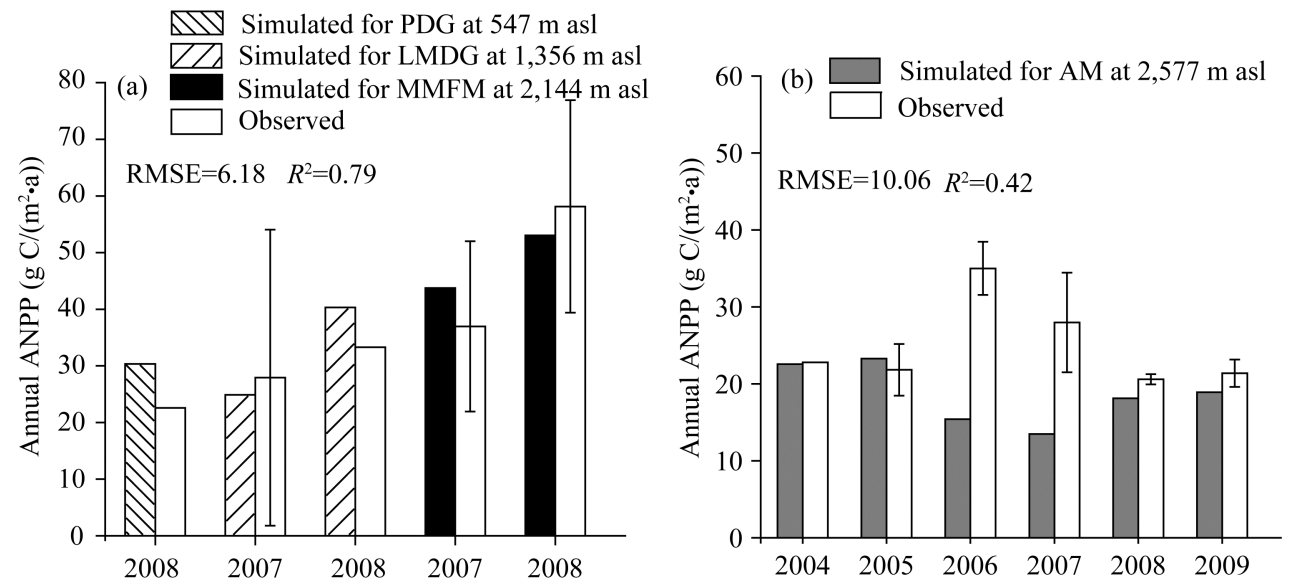

Fig. 2 Comparison of observed and simulated ANPP for grasslands at different elevations. a, Qitai area; b, Bayinbuluke area. AM, alpine meadow, 2,700-3,500 m asl; MMFM, mid-mountain forest meadow, 1,650-2,700 m asl; LMDG, low-mountain dry grassland, $650-1,650 \mathrm{~m}$ asl; PDG, plain desert grassland, $<650 \mathrm{~m}$ asl.

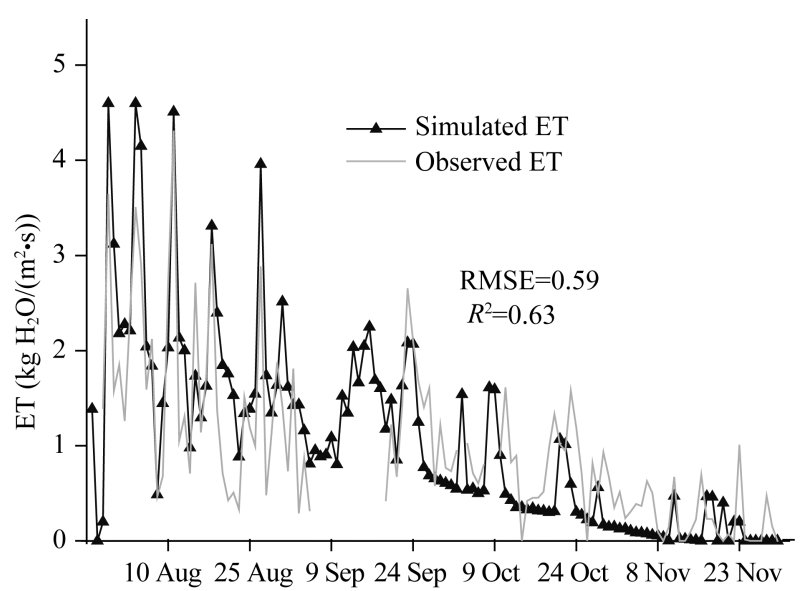

Fig. 3 Comparison of observed and simulated evapotranspiration (ET) for elevation 1,500 m asl, Qitai area between July 2012 and November 2012

\subsection{Altitudinal change in annual NPP}

Large changes in average annual NPP were observed across the 3,000-m range transect (Fig. 4). The values increased with the increase of elevation, reached their maximum at the mid-high elevation site, and then decreased above the mid-high elevation site. The grassland in the lower stand (at $400 \mathrm{~m}$ ) had, on average, an NPP 2.5 times lower than that in the upper stand (at $1,600 \mathrm{~m})$. The annual NPP increased from $83.20 \mathrm{~g}$ $\mathrm{C} /\left(\mathrm{m}^{2} \cdot \mathrm{a}\right)$ at $400 \mathrm{~m}$ asl to $161.73 \mathrm{~g} \mathrm{C} /\left(\mathrm{m}^{2} \cdot \mathrm{a}\right)$ at $1,600 \mathrm{~m}$ asl, for an average of $0.05 \mathrm{~g} \mathrm{C} /\left(\mathrm{m}^{2} \cdot \mathrm{a}\right)$ per $1-\mathrm{m}$ increase in elevation $\left(R^{2}=0.25\right)$. On the other hand, the annual NPP decreased to $58.99 \mathrm{~g} \mathrm{C} /\left(\mathrm{m}^{2} \cdot \mathrm{a}\right)$ at $3,400 \mathrm{~m}$ asl, with a decrease slope of $0.06 \mathrm{~g} \mathrm{C} /\left(\mathrm{m}^{2} \cdot \mathrm{a}\right)$ per $1-\mathrm{m}$ in- crease in elevation $\left(R^{2}=0.83\right)$. The sharp decrease of annual NPP from 2,600 to $2,800 \mathrm{~m}$ asl is due to the decrease of temperature.

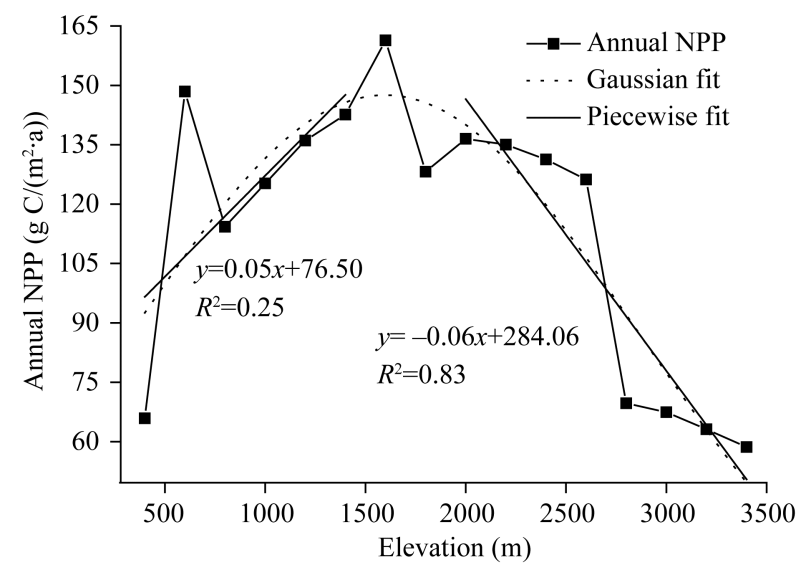

Fig. 4 Variability of annual net primary productivity (NPP) along the elevational gradient

\subsection{Climate effects and interannual variation of grassland NPP}

For each year of the three experiments (PreTem, PreFix and TemFix), we calculated the NPP at different elevations for the PDG site during 1971-2007 and for the other sites during 1959-2009 (Fig.5, Table 3). Table 3 shows that under the current climate scenario (PreTem), all the elevations presented significantly ascending NPP, with the most significance at the PDG site, which is $1.09 \mathrm{~g} \mathrm{C} /\left(\mathrm{m}^{2} \cdot \mathrm{a}\right)$. At the same time, for the PDG site, the precipitation change alone increased 
the NPP by $0.96 \mathrm{~g} \mathrm{C}\left(\mathrm{m}^{2} \cdot \mathrm{a}\right)$, and the temperature change alone reduced the NPP by $0.07 \mathrm{~g} \mathrm{C} /\left(\mathrm{m}^{2} \cdot \mathrm{a}\right)$, indicating that rising temperature increased the water stress at low elevations. At the other three sites, temperatures rather than precipitation played dominant roles. The PDG site $\left(1.09 \mathrm{~g} \mathrm{C} /\left(\mathrm{m}^{2} \cdot \mathrm{a}\right)\right)$ was much more sensitive to climate variation than other sites $\left(0.08-0.47 \mathrm{~g} \mathrm{C} /\left(\mathrm{m}^{2} \cdot \mathrm{a}\right)\right)$. Figure 5 shows the time series of the NPP anomalies from the three simulations relative to their corresponding averages during 1959-2009. The figure indicates that precipitation plays a dominant role at the PDG site (Fig. 5a), while
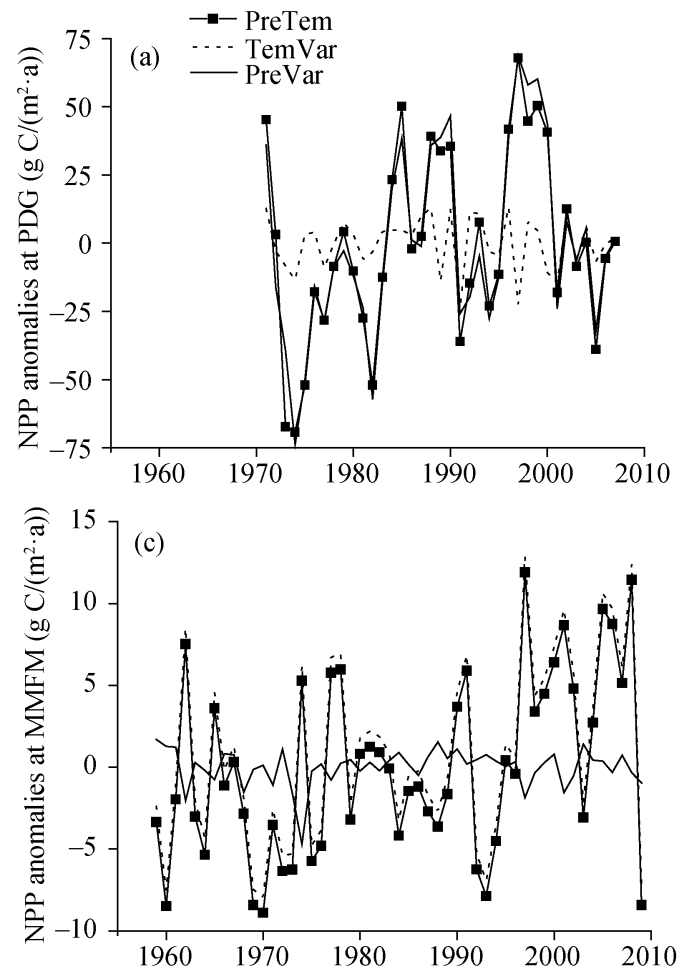

Table 3 Annual Trend of NPP at different elevations from two different Biome-BGC experiments during 1959-2007

\begin{tabular}{lllllll}
\hline Grassland & \multicolumn{6}{c}{ Scenario } \\
\cline { 2 - 7 } & PreTem & $\begin{array}{l}R^{2}(P< \\
0.05)\end{array}$ & TemVar & $R^{2}(P<0.05)$ & PreVar & $\begin{array}{l}R^{2}(P< \\
0.05)\end{array}$ \\
\hline PDG & 1.09 & 0.12 & -0.07 & 0.12 & 0.96 & 0.22 \\
LMDG & 0.47 & 0.06 & 0.36 & 0.01 & -0.02 & 0.19 \\
MMFM & 0.16 & 0.18 & 0.06 & 0.01 & 0.01 & 0.19 \\
AM & 0.08 & 0.12 & 0.07 & 0.01 & -0.01 & 0.19 \\
\hline
\end{tabular}

Note: PreTem, variable precipitation and temperature; TemVar, fixed precipitation and variable temperature; PreVar, fixed temperature and variable precipitation.
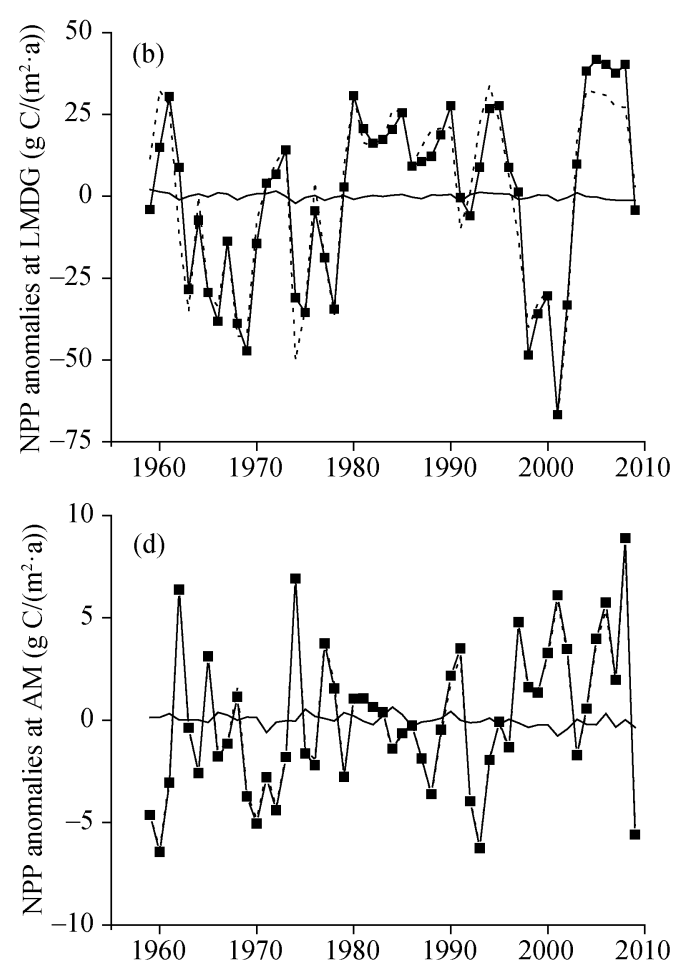

Fig. 5 NPP anomalies in four different grassland types along the elevational gradient during 1959-2009 as estimated by Biome-BGC from three different simulations: PreTem (variable precipitation and temperature), TemVar (fixed precipitation and variable temperature) and PreVar (fixed temperature and variable precipitation).

temperature contributes more at the other three sites (Figs. 5b-d).

\subsection{WUE along the elevational gradient}

There was a noticeable difference in the values of WUE along the elevational gradient. As shown by Fig. 6, the 51-year (1959-2009) annual average WUE ranges between $0.58 \mathrm{~g} \mathrm{C} / \mathrm{kg} \mathrm{H}_{2} \mathrm{O}$ at $600 \mathrm{~m}$ asl and
$0.26 \mathrm{~g} \mathrm{C} / \mathrm{kg} \mathrm{H}_{2} \mathrm{O}$ at $2,800 \mathrm{~m}$ asl. The WUE is higher at lower elevations with less precipitation. However, a decreasing trend with decreasing elevations at the driest end of the gradient at approximately 400-700 m asl was found (Fig. 6a). This trend is explored in detail and is plotted in Fig. 6b, whereby we can conclude that the turning point from high to low WUE is at approximately $540 \mathrm{~m}$ asl. 

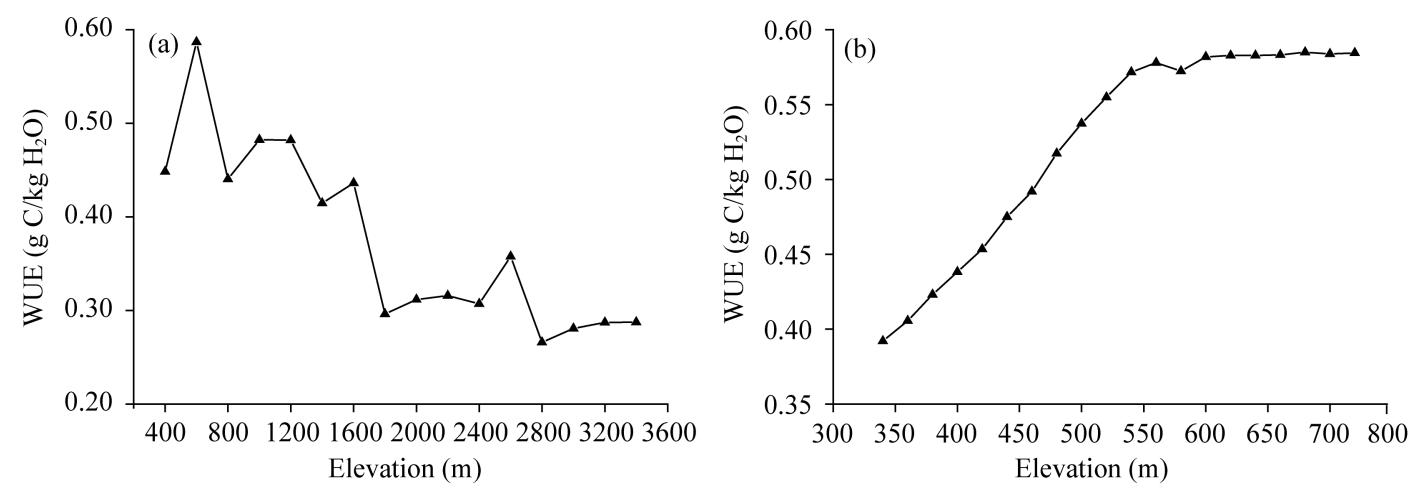

Fig. 6 The 51-year (1959-2009) averages of water-use efficiency (WUE) for different elevations

\section{Discussion}

In this study, we assumed that the sixteen modeled sites contained similar plant species. At the same time, we ensured that they were located at the same aspect and relief and were free of significant human disturbance. Hence, the sites represent a well-defined elevational transect.

Because the Biome-BGC model had been developed and parameterized using field data from arid lands in Xinjiang, we expected a good model performance in the mountainous zones of our study area. The findings of our investigation generally support these expectations. The examination of the simulation results showed no significant bias, which reveals that the adjusted Biome-BGC performs quite well in TMJB. However, there are still several factors that may involve uncertainty in the model performance. First, most of the parameters were utilized in the way as reported in the literature rather than using field data. Although these parameters are not vital for model performance, inaccuracy may exist. Second, other vital site-specific information was limited, e.g. soil texture and soil depth. These parameters were also adjusted to reflect site class conditions (Cienciala and Tatarinov, 2006). Biome-BGC remains sufficiently systematic considering the number of processes included. Several minor issues that could be improved have been identified, such as the way of identifying phenology and evaporation from wet crown and ground water utilization (Pietsch et al., 2003). Further studies should be conducted in these respects.

The NPP simulated by Biome-BGC, presented here, is consistent with the field data. With no anthropological effects included in the simulations, we observed significant elevational trends in NPP for the selected sites. NPP was greatest at the site with an elevation of $1,600 \mathrm{~m}$ asl. The site at $600 \mathrm{~m}$ asl had an abnormally large NPP, and we speculated that this may be related to the groundwater level (Chhabra and Kumar, 2008). However, the WUE analysis showed that this result may be due to the lower WUE in this area.

Annual temperature was used as one of the major climatic factors that govern the activity of land vegetation in the inter-annual deviations of net primary productivity (Mohamed et al., 2004). The positive correlations between temperature and NPP at higher elevations (MMFM and AM) reflect their responses to warmer temperatures through enhancing plant production. The grasslands at lower elevations displayed unobvious or negative correlations, which may be attributed to an increase in water stress in these water-deficient environments due to warmer temperatures (Braswell et al., 1997). These findings are in accordance with the research carried out by Mohamed et al. (2004). They concluded that positive correlations exist between temperature anomalies and NPP anomalies in tropical deciduous, temperate and boreal forests and that negative correlations exist in temperate grassland and savanna because of the differences of water availability and temperature factors.

Positive correlations were found between NPP and annual precipitation in the grassland at lower elevations, which indicates a direct enhancement of vegetation production following increased precipitation, in 
agreement with the observation of Goward and Prince (1995). However, with the increase of elevation, no obvious or negative relationship between NPP and precipitation was found, which may be attributed to a lower photosynthetic rate due to lower temperature. As shown by our findings, interactions between climate and NPP have proven to be important in the evaluation of the effects of climate change on terrestrial ecosystems (Schimel et al., 1990; McGuire et al., 1992).

Our results indicate an increase (approximately $\left.0.41 \mathrm{~g} \mathrm{C} /\left(\mathrm{m}^{2} \cdot \mathrm{a}\right)\right)$ in mean NPP for the grassland in TMJB under a real climate change scenario. This increase has been corroborated by Nemani et al. (2003) and Hyvönen et al. (2007), who concluded that the recent climate changes have enhanced plant growth in the northern mid- and high-latitudes, and multiple mechanisms have promoted increases in NPP. Although the NPP change cannot be completely attributed to long-term historical climate change, the continuously strong climate changes in TMJB from 1959 to 2009 have clearly accelerated the ecological change process and have influenced the spatial patterns of ecosystem to a certain extent. This study represented a comprehensive 51-year examination of the elevational and temporal variation in NPP in TMJB using a biogeochemical model. The overall conclusion from this analysis is that climate change has strongly influenced the NPP of grassland ecosystems.

WUE is higher at lower elevations that are water-stressed due to the plants' nature of regulating the exchange of $\mathrm{CO}_{2}$ and water vapor (Monteith and Greenwood, 1986). The implementation of ecosystem models will necessitate a comprehensive understanding of the WUE of various land condition classes (Palmer et al., 2011). Remarkable differences in WUE were found among different elevations. We predicted that WUE would increase significantly with decreasing water availability at lower elevations, in agreement with Lajtha and Getz (1993). In addition, Ito and Inatomi (2012) modeled the WUE of the global terrestrial biosphere and found that arid biomes such as desert and shrub land had higher WUE values than humid environments. Although studies using watering treatments have shown decreases in WUE with in- creases in water availability (Comstock and Ehleringer, 1986; Lajtha and Whitford, 1989; Toft et al., 1989), this study differs in that we used gradients of natural communities with the original plant density, spatial patterns and soil water availability. We did observe a decreasing trend with decreasing elevation below 400 $\mathrm{m}$ asl, in agreement with the WUE modeled by Lajtha and Getz (1993) using $\delta^{13} \mathrm{C}$ values of photosynthetic tissues. This decreasing trend may be due to the sharp changes in canopy cover over this gradient. Furthermore, White and Snow (2012) also illustrated that increasing root depth increased WUE and decreasing root depth decreased WUE, but the extents of the negative deviations in WUE were influenced by climate, irrigation, and soil treatments. Here in our study, root depth was not considered because of the limitation of the model. This will be further studied in the future.

These estimates using the Biome-BGC model provide a robust method for establishing the WUE of grasslands along geographical gradients. This method provides the ability to predict annual biomass production and ET in arid grasslands. The approach outlined in this research demonstrates how biomass production and ET can be accurately measured at a landscape scale. Changes in WUE may assist in determining whether an ecosystem is degrading (Holm et al. 2003), and it is necessary to calculate water-use efficiencies for other ecosystems in a range of condition classes.

\section{Conclusion}

The results presented in our research suggest that the NPP simulated by Biome-BGC is consistent with observed data along the elevational transect in TMJB. During the attempt to assess the inter-annual variability of the NPP of the grassland ecosystem over 51 years (1959-2009) in relation to climate factors, we established some significant correlations that are important in the evaluation of the effects of climate change on terrestrial ecosystems.

The magnitude and sign of vegetation response to climate variation is largely dependent on elevation. At lower elevations, precipitation was found to dictate 
most of the inter-annual variation of the NPP, while at higher elevations temperature had the greatest effect. NPP responses represent a mixture of different responses, which are complicated by the spatial variability of climate and land use factors. More attention should be given to the interactions between the short-term (annual) and long-term (decadal) dynamics of vegetation production and climate variability, which are still associated with large uncertainty.

Although WUE was significantly greater at the driest sites over this gradient, other factors compensated for the decreased water availability, which can result in a constant trend at some elevations. Our study using modeling provides the opportunity to further evaluate and test interactions between plants and environmental factors, which is rarely achievable in field studies. The results obtained could be significant for studies of plant productivity over elevational gradients where species change in life forms.

This study represents a pioneering attempt to fully assess the long-term changes of NPP, ET, and WUE with the goal of understanding the interactions between carbon and water resources under multiple stresses along an elevational gradient. Certainly, the contributions of different environmental factors to NPP, ET and WUE need to be further identified in future studies. In addition, the adjusted Biome-BGC model performs quite well in TMJB, however, there are still several reasons for the uncertainty in the model performance. Future studies should be conducted to analyze the uncertainty of the model performance.

\section{Acknowledgments}

This research is funded by the National Natural Science Foundation of China (41271126) and the National Basic Research Program of China (2009CB825105).

\section{References}

Austin M P, Pausas J G, Nicholls A O. 1996. Patterns of tree species richness in relation to environment in south-eastern New South Wales, Australia. Australian Journal of Ecology, 21: 154-164.

Bai Y F, Wu J G, Xing Q, et al. 2008. Primary production and rain use efficiency across a precipitation gradient on the Mongolia plateau.
Ecology, 89(8): 2140-2153.

Braswell B H, Schimel D S, Linder E, et al. 1997. The response of global terrestrial ecosystems to interannual temperature variability. Science, 278(5339): 870-873.

Cheng C S, Auld H, Li Q, et al. 2012. Possible impacts of climate change on extreme weather events at local scale in south-central Canada. Climatic Change, 112(3-4): 963-979.

Chhabra R, Kumar A. 2008. Effect of water-table depths and groundwater salinities on the growth and biomass production of different forest species. Indian Journal of Agricultural Sciences, 78(9): 785-790.

Chiesi M, Maselli F, Moriondo M, et al. 2007. Application of Biome-BGC to simulate Mediterranean forest processes. Ecological Modelling, 206(1-2): 179-190.

Churkina G, Running S W. 1998. Contrasting climatic controls on the estimated productivity of global terrestrial biomes. Ecosystems, 1(2): 206-215.

Cienciala E, Tatarinov F A. 2006. Application of Biome-BGC model to managed forests: 2. comparison with long-term observations of stand production for major tree species. Forest Ecology and Management, 237(1-3): 252-266.

Comstock J, Ehleringer J. 1986. Canopy dynamics and carbon gain in response to soil water availability in Encelia frutescens gray, a drought-deciduous shrub. Oecologia, 68(2): 271-278.

DeLucia E H, Schlesinger W H. 1991. Resource-use efficiency and drought tolerance in adjacent Great Basin and Sierran plants. Ecology, 72(1): 51-58.

Diaz H F, Grosjean M, Graumlich L. 2003. Climate variability and change in high elevation regions: past, present and future. Climatic Change, 59(1): 1-4.

Drewnik M. 2006. The effect of environmental conditions on the decomposition rate of cellulose in mountain soils. Geoderma, 132(1-2): 116-130.

Easterling D R, Meehl G A, Parmesan C, et al. 2000. Climate extremes: observations, modeling, and impacts. Science, 289(5487): 2068-2074.

Ehleringer J R, Cooper T A. 1988. Correlations between carbon isotope ratio and microhabitat in desert plants. Oecologia, 76(4): 562-566.

Farquhar G D, Caemmerer S, Berry J A. 1980. A biochemical model of photosynthetic $\mathrm{CO}_{2}$ assimilation in leaves of $\mathrm{C}_{3}$ species. Planta, 149(1): 78-90.

Goward S N, Prince S D. 1995. Transient effects of climate on vegetation dynamics: satellite observations. Journal of Biogeography, 22(2/3): 549-564.

Hall D O, Ojima D S, Parton W J, et al. 1995. Response of temperate and tropical grasslands to $\mathrm{CO}_{2}$ and climate change. Journal of Biogeography, 22(2/3): 537-547.

Hidy D, Barcza Z, Haszpra L, et al. 2012. Development of the Biome-BGC model for simulation of managed herbaceous 
ecosystems. Ecological Modelling, 226: 99-119.

Hu Z M, Yu G R, Fan J W, et al. 2010. Precipitation-use efficiency along a 4500-km grassland transect. Global Ecology and Biogeography, 19(6): 842-851.

Huxman T E, Smith M D, Fay P A, et al. 2004. Convergence across biomes to a common rain-use efficiency. Nature, 429(6992): 651-654.

Hyvönen R, Ågren G I, Linder S, et al. 2007. The likely impact of elevated $\mathrm{CO}_{2}$, nitrogen deposition, increased temperature and management on carbon sequestration in temperate and boreal forest ecosystems: a literature review. New Phytologist, 173(3): 463-480.

Ito A, Inatomi M. 2012. Water-use efficiency of the terrestrial biosphere: a model analysis focusing on interactions between the global carbon and water cycles. Journal of Hydrometeorology, 13(2): 681-694.

Justice C O, Dugdale G, Townshend J R G, et al. 1991. Synergism between NOAA-AVHRR and Meteosat data for studying vegetation development in semi-arid West Africa. International Journal of Remote Sensing, 12(6): 1349-1368.

Kimball J S, Thornton P E, White M A, et al. 1997. Simulating forest productivity and surface-atmosphere carbon exchange in the BOREAS study region. Tree Physiology, 17(8-9): 589-599.

Knapp A K, Fay P A, Blair J M, et al. 2002. Rainfall variability, carbon cycling, and plant species diversity in a mesic grassland. Science, 298(5601): 2202-2205.

Lagergren F, Grelle A, Lankreijer H, et al. 2006. Current carbon balance of the forested area in Sweden and its sensitivity to global change as simulated by Biome-BGC. Ecosystems, 9(6): 894-908.

Lajtha K, Whitford W G. 1989. The effect of water and nitrogen amendments on photosynthesis, leaf demography, and resource-use efficiency in Larrea tridentata, a desert evergreen shrub. Oecologia, 80(3): 341-348.

Lajtha K, Getz J. 1993. Photosynthesis and water-use efficiency in pinyon-juniper communities along an elevation gradient in northern New Mexico. Oecologia, 94(1): 95-101.

LeHouerou H N. 1984. Rain use efficiency: a unifying concept in arid-land ecology. Journal of Arid Environments, 7(3): 213-247.

Luo G, Han Q, Zhou D, et al. 2012. Moderate grazing can promote aboveground primary production of grassland under water stress. Ecological Complexity, 11: 126-136.

Luo T, Pan Y, Ouyang H, et al. 2004. Leaf area index and net primary productivity along subtropical to alpine gradients in the Tibetan Plateau. Global Ecology and Biogeography, 13(4): 345-358.

McGuire A D, Melillo J M, Joyce L A, et al. 1992. Interactions between carbon and nitrogen dynamics in estimating net primary productivity for potential vegetation in North America. Global Biogeochem. Cycles, 6(2): 101-124.

Melillo J M, Mcguire A D, Kicklighter D W, et al. 1993. Global Climate-change and terrestrial net primary production. Nature, 363(6426): 234-240.
Messerli B, Ives J D. 1997. Mountains of the World: A Global Priority. Parthenon, New York: Parthenon Publishing, 328-329.

Mohamed M A A, Babiker I S, Chen Z M, et al. 2004. The role of climate variability in the inter-annual variation of terrestrial net primary production (NPP). Science of the Total Environment, 332(1-3): 123-137.

Monteith J L, Greenwood D J. 1986. How do crops manipulate water supply and demand? Philosophical Transactions of the Royal Society of London. Series A, Mathematical and Physical Sciences, 316(1537): 245-259.

Nemani R R, Keeling C D, Hashimoto H, et al. 2003. Climate-driven increases in global terrestrial net primary production from 1982 to 1999. Science, 300(5625): 1560-1563.

Ning B Y, Yang X M, Chang L. 2012. Changes of temperature and precipitation extremes in Hengduan Mountains, Qinghai-Tibet Plateau in 1961-2008. Chinese Geographical Science, 22(4): 422-436.

Palmer A R, Short A, Yunusa I. 2011. Biomass production and water use efficiency of grassland in the KwaZulu-Natal, South Africa. South African Journal of Botany, 77(2): 550-550.

Peng J, Gou X, Chen F, et al. 2008. Altitudinal variability of climate-tree growth relationships along a consistent slope of Anyemaqen Mountains, northeastern Tibetan Plateau. Dendrochronologia, 26(2): 87-96.

Petritsch R, Hasenauer H, Pietsch S A. 2007. Incorporating forest growth response to thinning within biome-BGC. Forest Ecology and Management, 242(2-3): 324-336.

Pietsch S A, Hasenauer H, Kucera J, et al. 2003. Modelling effects of hydrological changes on the carbon and nitrogen balance of oak in flood-plains. Tree Physiology, 23: 735-746.

Prince S D, De Colstoun E B, Kravitz L L. 1998. Evidence from rain-use efficiency does not indicate extensive Sahelian desertification. Global Change Biology, 4(4): 359-374.

Repetto R, Easton R. 2010. Climate change and damage from extreme weather events. Environment, 52(2): 22-33.

Running S W, Coughlan J C. 1988. A general model of forest ecosystem processes for regional applications. I. hydrologic balance, canopy gas exchange and primary production processes. Ecological Modelling, 42(2): 125-154.

Running S W, Hunt R E. 1993. Generalization of a Forest Ecosystem Process Model for Other Biomes, BIOME-BGC, and an Application for Global-Scale Models. San Diego: Academic Press, 141-158.

Ryan M G. 1991. Effects of climate change on plant respiration. Ecological Applications, 1(2): 157-167.

Schimel D S, Parton W J, Kittel T G F, et al. 1990. Grassland biogeochemistry: links to atmospheric processes. Climatic Change, 17(1): 13-25.

Schmid S, Zierl B, Bugmann H. 2006. Analyzing the carbon dynamics of central European forests: comparison of Biome-BGC simulations 
with measurements. Regional Environmental Change, 6(4): $167-180$.

Shen W P, Ren S J, Yu G R, et al. 2011. Patterns and driving factors of WUE and NUE in natural forest ecosystems along the North-South Transect of Eastern China. Journal of Geographical Sciences, 21(4): 651-665.

Tatarinov F A, Cienciala E. 2006. Application of Biome-BGC model to managed forests 1. sensitivity analysis. Forest Ecology and Management, 237(1-3): 267-279.

Thompson L G. 2000. Ice core evidence for climate change in the Tropics: implications for our future. Quaternary Science Reviews, 19(1-5): 19-35.

Thornton P E, Running S W. 1999. An improved algorithm for estimating incident daily solar radiation from measurements of temperature, humidity, and precipitation. Agricultural and Forest Meteorology, 93(4): 211-228.

Thornton P E, Hasenauer H, White M A. 2000. Simultaneous estimation of daily solar radiation and humidity from observed temperature and precipitation: an application over complex terrain in Austria. Agricultural and Forest Meteorology, 104(4): 255-271.

Toft N L, Anderson J E, Nowak R S. 1989. Water use efficiency and carbon isotope composition of plants in a cold desert environment. Oecologia, 80(1): 11-18.

Ueyama M, Ichii K, Hirata R, et al. 2010. Simulating carbon and water cycles of larch forests in East Asia by the Biome-BGC model with AsiaFlux data. Biogeosciences, 7(3): 959-977.

Weltzin J F, Loik M E, Schwinning S, et al. 2003. Assessing the response of terrestrial ecosystems to potential changes in precipitation. Bioscience, 53(10): 941-952.

White T A, Snow V O. 2012. A modelling analysis to identify plant traits for enhanced water-use efficiency of pasture. Crop and Pasture Science, 63(1): 63-76.

Zhang H Y, Qian Y B, Wu Z N, et al. 2012. Vegetation-environment relationships between northern slope of Karlik Mountain and Naomaohu Basin, East Tianshan Mountains. Chinese Geographical Science, 22(3): 288-301. 